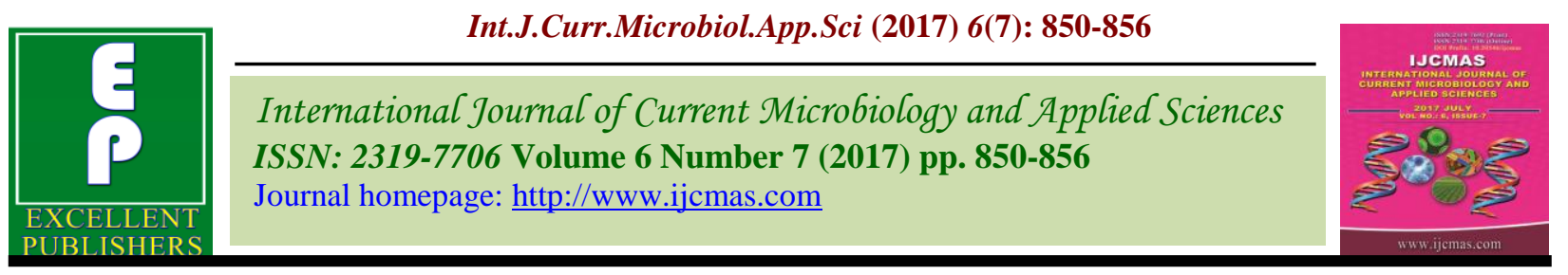

Original Research Article

https://doi.org/10.20546/ijcmas.2017.607.104

\title{
Genetic Diversity Studies in Minicore Collection of Rabi Sorghum [Sorghum bicolor. (L)] Using $\mathrm{D}^{2}$ Statistics
}

\author{
Bhima Hari Vara Prasad and B.D. Biradar*
}

Department of Genetics and plant breeding, University of Agricultural sciences,

Dharwad, Karnataka, India

*Corresponding author

\section{A B S T R A C T}

Sorghum is the important cereal crop around the world and hence understanding

Keywords

Sorghum, Inter-

cluster, Genetic

divergence, $\mathrm{D}^{2}$

statistics and

Segregants.

Article Info

Accepted:

14 June 2017

Available Online:

10 July 2017 and utilizing the genetic variation in sorghum accessions are essential for improving the crop. A good understanding of genetic variability among the accessions will enable precision breeding. So profiling the genetic diversity of sorghum is imminent. The $\mathrm{D}^{2}$ statistics was applied to assess the diversity among 228 genotypes of sorghum. The analysis of variance revealed significant differences among the genotypes for all the characters under study. The genotypes were grouped into 22 clusters, where cluster I comprised maximum of 115 genotypes followed by cluster II with 45 genotypes each. Inter-cluster distance was maximum between the clusters III and XXI followed by XIII and XXI with 33.50 and 33.26 each which indicated that genotypes included in these clusters may give heterotic response and thus better segregants. Regarding genetic divergence of the genotypes, panicle weight contributed major share followed by primaries per panicle with $25.64 \%$ and $22.92 \%$ each, these traits can be utilized for future crop improvement programme.

\section{Introduction}

Sorghum is one of the most important cereal crop grown in Africa, Asia, USA, Australia, and Latin America. Its importance after wheat, maize, rice and barley is because of its good adaptation to a wide range of ecological conditions, low input cultivation and diverse uses (Aruna et al., 2011). In India, it is third major cereal after rice and wheat and it is most important food crop grown under rainfed conditions. Knowledge of genetic diversity of a crop usually helps the breeder in choosing desirable parents for the breeding program and gene introgression from distantly

related germplasm. The more diverse genotypes or accessions can be crossed to produce superior hybrids with resistance to abiotic and biotic stresses. Understanding the wealth of genetic diversity in sorghum will facilitate further improvement of this crop for its genetic architecture (Santosh et al., 2015).

The present study were undertaken to analyze the genetic diversity among the quantitative traits in sorghum germplasm accessions received from ICRISAT. It also aimed to characterize the germplasm for certain useful 
agro-morphological traits. The identified accessions may prove to be an important gene pool for different traits.

The basis for genetic enhancement in any crop is systematic assessment of variability and genetic diversity available in the germplasm. The most widely used technique to assess the genetic diversity is Mahalanobis's $\mathrm{D}^{2}$ statistic. In the present study, this technique has been applied to assess the diversity among 228 sorghum genotypes.

\section{Materials and Methods}

The present field experiment on sorghum (Sorghum bicolor L. Moench) was conducted at botanical garden, Dept of genetics and plant breeding, UAS, Dharwad in rabi 201516. All the recommended agronomic practices were followed to raise a good crop. The experiment was laid out in randomized block design with two replications and row of $4 \mathrm{~m}$ length and spacing of $45 \times 15 \mathrm{~cm}$.

The observations were recorded on five randomly selected plants for characters chlorophyll at flag leaf stage, chlorophyll at maturity, days to $50 \%$ flowering, days to maturity, plant height, panicle length, panicle width, 100 seed weight, panicle weight, primaries per panicle and grain yield per plant.

The data was subjected to statistical analysis. Wilk's criteria were used to test the significance of pooled differences in mean values for all the sixteen characters. Genetic diversity was studied using Mahalanobis's (1936) $\mathrm{D}^{2}$ statistic and clustering of genotypes was done according to Tocher's method.

\section{Results and Discussion}

Analysis of variance revealed the significant differences among genotypes for all characters under study. Based on $\mathrm{D}^{2}$ statistics and Tocher's method 228 genotypes were grouped into 22 clusters with a variable number of entries revealing the presence of considerable amount of genetic diversity in the material (Table 1). The cluster I comprised of maximum number of 115 genotypes each followed by cluster II with 45 genotypes. III and VII have 23 genotypes and 20 genotypes each. XVIII and XXI have 3 genotypes each, while the rest of the clusters had one genotype each. The pattern of distribution of genotypes into various clusters was at random suggesting that the genetic diversity was not related to geographic diversity. Similar results were reported by Sameer Kumar et al., (2010) in genetic divergence studies in rabi sorghum.

Average intra and inter-cluster $\mathrm{D}^{2}$ (Table 4) values among all genotypes revealed that the solitary clusters showed intra-cluster value of 0.00, while cluster XVIII (11.22) showed maximum intra-cluster distance.

The inter-cluster $\mathrm{D}^{2}$ values ranged from 4.56 to 33.50. Minimum inter-cluster $\mathrm{D}^{2}$ values were observed between clusters IV and VI indicating the close relationship among the genotypes included in these clusters. Maximum inter-cluster values were observed between the clusters III and XXI followed by XIII and XXI with 33.50 and 33.26 each which indicated that genotypes included in these clusters may give heterotic response followed with better segregants. These results are in conformity with Shivani and Sreelakshmi (2013) and Dojjad et al., (2016).

The cluster means and contribution of each trait towards divergence are presented in (Tables 2 and 3).

The data revealed considerable differences among the clusters for most of the characters studied. Cluster XXI recorded the highest mean for plant height, panicle weight and 
grain yield per plant, whereas cluster XXII recorded the highest mean for chlorophyll at flag leaf stage, days to maturity, panicle width and the lowest mean for grain yield per plant.
Cluster VI recorded the highest mean for primaries per panicle and lowest mean value for panicle weight. Cluster XIX recorded the lowest mean for 100 seed weight.

Table.1 Distribution of sorghum genotypes in twenty two different clusters

\begin{tabular}{|c|c|c|}
\hline $\begin{array}{c}\text { Cluster } \\
\text { No. }\end{array}$ & Name of genotypes & $\begin{array}{c}\text { No. of } \\
\text { genotypes }\end{array}$ \\
\hline I & 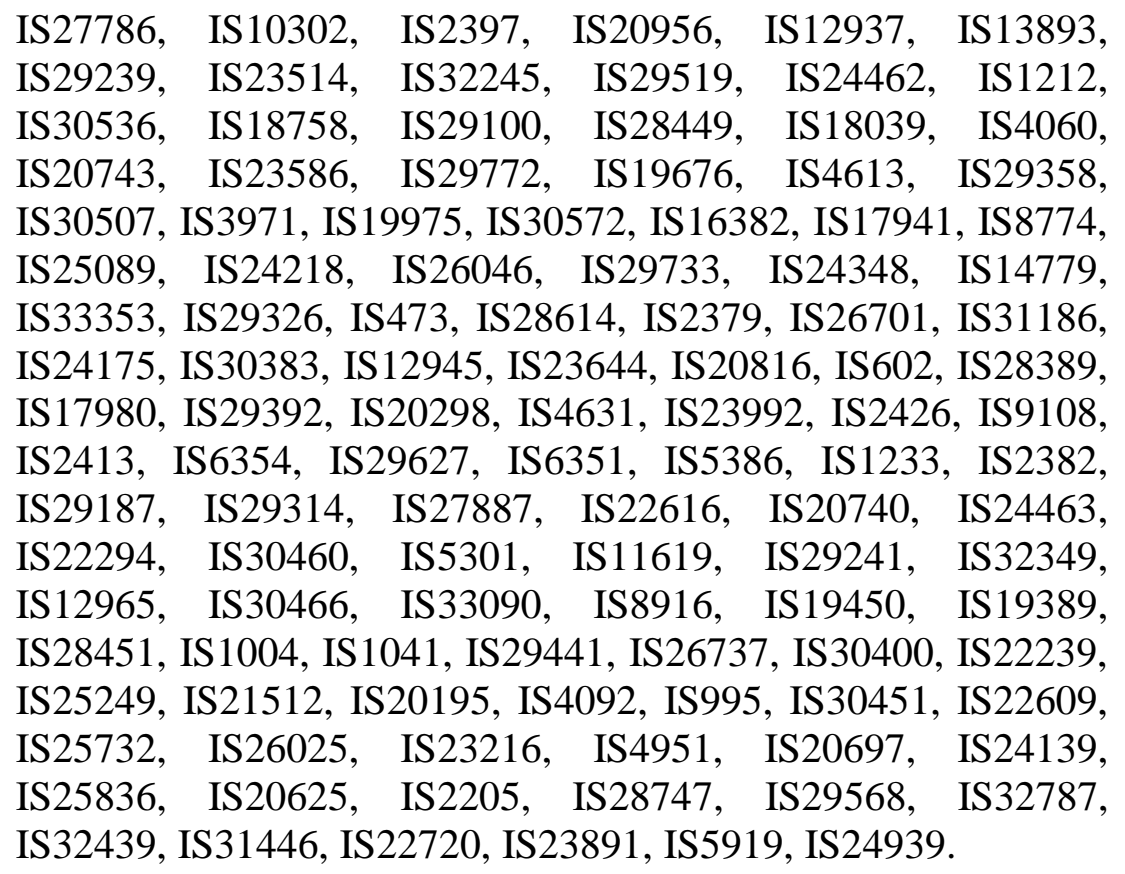 & 115 \\
\hline II. & $\begin{array}{l}\text { IS20713, IS4698, IS27912, IS12735, IS15466, IS15170, } \\
\text { IS19445, IS7305, IS29606, IS10867, IS2902, IS12302, IS15945, } \\
\text { IS23590, IS12447, IS28849, IS5667, IS30079, IS8348, IS19153, } \\
\text { IS26694, IS603,IS21645, IS8777, IS14010, IS14290, IS10969, } \\
\text { IS3158, IS24453, IS24953, IS30092, IS21863, IS30231,IS23684, } \\
\text { IS4515, IS29689, IS2864, IS15931, IS20727, IS33023, IS29091, } \\
\text { IS20632, IS22986, IS5094, IS30838, IS19859, IS10757 }\end{array}$ & 47 \\
\hline III. & $\begin{array}{l}\text { IS3121, IS30443, IS12706, IS31651, IS19262, IS25989, } \\
\text { IS29714, IS9177, IS22799IS4581, IS30533, IS13919, IS7131, } \\
\text { IS29269, IS7310, IS16528, IS23579, IS30417, IS27034, IS7679, } \\
\text { IS33844, IS16151, IS5295 }\end{array}$ & 23 \\
\hline IV. & IS14861 & 1 \\
\hline V. & IS29950 & 1 \\
\hline VI. & IS31714 & 1 \\
\hline VII. & $\begin{array}{l}\text { IS30450, IS26617, IS2389, IS2872, IS12883, IS29304, IS29914, } \\
\text { IS25910, IS8012, IS7250, IS24492, IS15744, IS9745, IS7957, } \\
\text { IS31043, IS24503, IS29335, IS30562, IS6421, IS11026 }\end{array}$ & 20 \\
\hline
\end{tabular}




\begin{tabular}{|l|l|c|}
\hline VIII. & IS4372 & 1 \\
\hline IX. & IS23521 & 1 \\
\hline X. & IS29654 & 1 \\
\hline XI & IS31706 & 1 \\
\hline XII & IS13549 & 1 \\
\hline XIII & IS27557 & 1 \\
\hline XIV & IS26749 & 1 \\
\hline XV & IS28313 & 1 \\
\hline XVI & IS11473 & 1 \\
\hline XVII & IS29468 & 3 \\
\hline XVIII & IS25301, IS1219, IS26484 & 1 \\
\hline XIX & IS12697 & 1 \\
\hline XX & IS13971 & 3 \\
\hline XXI & IS7987, IS4360, IS12804 & 1 \\
\hline XXII & IS20679 & 1 \\
\hline
\end{tabular}

Table.2 Percentage contribution of different characters towards Genetic divergence in rabi sorghum

\begin{tabular}{|l|l|l|}
\cline { 2 - 3 } S.No & Characters & Contribution \% \\
\hline 1 & chlorophyll @ flag leaf stage & $0.30 \%$ \\
\hline 2 & chlorophyll @ maturity stage & $17.91 \%$ \\
\hline 3 & Days to 50\%flowering & $0.02 \%$ \\
\hline 4 & Days to maturity & $0.08 \%$ \\
\hline 5 & plant height $(\mathrm{cm})$ & $0.18 \%$ \\
\hline 6 & panicle length $(\mathrm{cm})$ & $0.28 \%$ \\
\hline 7 & panicle width $(\mathrm{cm})$ & $2.40 \%$ \\
\hline 8 & panicle weight $(\mathrm{g})$ & $25.64 \%$ \\
\hline 9 & primaries per panicle & $22.92 \%$ \\
\hline 10 & 100 seed weight $(\mathrm{g})$ & $12.42 \%$ \\
\hline 11 & yield/plant $(\mathrm{g})$ & $17.85 \%$ \\
\hline
\end{tabular}




\begin{tabular}{|c|c|c|c|c|c|c|c|c|c|c|c|}
\hline \multicolumn{12}{|c|}{ Table.3 Cluster means for eleven characters in rabi sorghum } \\
\hline $\begin{array}{c}\text { Cluster } \\
\text { No }\end{array}$ & $\begin{array}{c}\text { Chlorophyll } \\
\text { @flag leaf } \\
\text { stage }\end{array}$ & $\begin{array}{c}\text { Chlorophyll } \\
\text { @maturity } \\
\text { stage }\end{array}$ & $\begin{array}{c}\text { Days to } \\
50 \% \\
\text { flowering }\end{array}$ & $\begin{array}{l}\text { Days to } \\
\text { maturity }\end{array}$ & $\begin{array}{c}\text { Plant } \\
\text { height }\end{array}$ & $\begin{array}{c}\text { Panicle } \\
\text { length }\end{array}$ & $\begin{array}{c}\text { Panicle } \\
\text { width }\end{array}$ & $\begin{array}{c}\text { Panicle } \\
\text { weight }\end{array}$ & $\begin{array}{c}\text { Primaries } \\
\text { per } \\
\text { panicle }\end{array}$ & $\begin{array}{c}\text { 100seed } \\
\text { weight }\end{array}$ & $\begin{array}{c}\text { Yield } \\
\text { per } \\
\text { plant }\end{array}$ \\
\hline I & 51.09 & 37.74 & 73.56 & 133.78 & 190.08 & 22.99 & 7.10 & 22.38 & 26.63 & 2.77 & 17.38 \\
\hline II & 51.87 & 41.77 & 73.98 & 133.50 & 200.44 & 22.44 & 7.46 & 42.20 & 32.46 & 3.24 & 32.48 \\
\hline III & 49.93 & 27.35 & 71.80 & 134.98 & 186.41 & 24.91 & 7.20 & 14.73 & 23.77 & 2.91 & 12.08 \\
\hline IV & 44.69 & 43.30 & 79.50 & 138.50 & 174.00 & 24.00 & 6.95 & 19.40 & 27.00 & 5.15 & 19.20 \\
\hline $\mathrm{V}$ & 49.87 & 23.00 & 77.50 & 139.00 & 160.00 & 21.75 & 8.85 & 29.50 & 30.00 & 3.18 & 29.00 \\
\hline VI & 52.48 & 38.92 & 67.50 & 132.00 & 149.50 & 12.95 & 5.35 & 25.00 & 21.84 & 5.03 & 19.02 \\
\hline VII & 49.82 & 36.67 & 76.43 & 133.65 & 191.75 & 26.08 & 8.77 & 28.03 & 37.58 & 3.15 & 22.85 \\
\hline VIII & 48.99 & 49.20 & 60.00 & 138.00 & 182.00 & 16.63 & 5.10 & 12.79 & 16.67 & 4.26 & 9.60 \\
\hline IX & 47.57 & 48.31 & 74.50 & 133.50 & 174.00 & 24.25 & 7.95 & 62.42 & 34.74 & 3.09 & 46.51 \\
\hline$X$ & 40.87 & 23.8 & 74.00 & 142.50 & 200.00 & 22.25 & 5.85 & 29.50 & 20.00 & 2.83 & 32.00 \\
\hline $\mathrm{X} 1$ & 44.98 & 35.22 & 73.00 & 139.50 & 208.50 & 28.85 & 11.30 & 19.73 & 27.00 & 5.77 & 19.50 \\
\hline XII & 53.98 & 49.50 & 79.00 & 131.50 & 196.50 & 22.75 & 10.50 & 65.05 & 39.32 & 1.92 & 49.75 \\
\hline XIII & 43.58 & 52.80 & 90.50 & 156.50 & 215.00 & 22.33 & 9.40 & 10.9 & 14.17 & 2.49 & 15.99 \\
\hline XIV & 55.50 & 27.00 & 75.50 & 125.00 & 126.50 & 22.25 & 5.35 & 42.00 & 21.00 & 2.20 & 22.00 \\
\hline $\mathrm{XV}$ & 45.55 & 41.33 & 76.00 & 142.00 & 225.00 & 21.15 & 8.25 & 59.71 & 37.77 & 2.60 & 55.68 \\
\hline XVI & 52.50 & 42.24 & 67.00 & 121.00 & 168.50 & 20.25 & 6.85 & 62.00 & 36.00 & 4.53 & 24.00 \\
\hline XVII & 49.00 & 39.35 & 72.50 & 129.00 & 170.00 & 18.25 & 7.45 & 43.40 & 52.70 & 3.19 & 37.50 \\
\hline XVIII & 43.88 & 32.85 & 77.17 & 130.17 & 236.00 & 24.33 & 7.27 & 50.70 & 22.86 & 2.92 & 16.89 \\
\hline XIX & 46.37 & 25.00 & 68.50 & 141.00 & 236.00 & 25.75 & 13.35 & 37.50 & 35.00 & 1.32 & 40.00 \\
\hline XX & 52.40 & 40.30 & 70.50 & 126.50 & 223.00 & 29.55 & 7.05 & 6.18 & 49.00 & 2.65 & 15.61 \\
\hline XXI & 51.33 & 41.30 & 68.83 & 130.50 & 233.33 & 25.47 & 6.70 & 79.82 & 43.51 & 3.44 & 62.96 \\
\hline XXII & 78.67 & 30.00 & 66.50 & 143.50 & 174.00 & 20.13 & 11.43 & 15.30 & 45.00 & 3.47 & 6.41 \\
\hline
\end{tabular}




\begin{tabular}{|c|c|c|c|c|c|c|c|c|c|c|c|c|c|c|c|c|c|c|c|c|c|c|}
\hline & I & II & III & IV & $\mathbf{V}$ & VI & VII & VIII & IX & $\mathbf{X}$ & X1 & XII & XIII & XIV & $\mathbf{X V}$ & XVI & XVII & XVIII & XIX & $\mathbf{X X}$ & XXI & XXII \\
\hline I & 7.67 & 13.00 & 10.41 & 9.68 & 9.30 & 9.62 & 11.50 & 10.18 & 19.80 & 10.00 & 11.86 & 21.94 & 11.50 & 10.03 & 21.45 & 16.64 & 19.17 & 13.07 & 13.62 & 15.12 & 28.85 & 14.10 \\
\hline II & & 8.30 & 17.38 & 12.10 & 11.00 & 12.4 & 11.9 & 16.4 & 11.10 & 13.00 & 14.15 & 13.51 & 17.18 & 12.58 & 12.85 & 10.91 & 13.29 & 13.75 & 11.34 & 17.93 & 19.74 & 17.98 \\
\hline III & & & 9.63 & 12.50 & 11.00 & 11.9 & 14.8 & 11.82 & 25.00 & 12.00 & 13.06 & 27.34 & 14.00 & 12.07 & 26.38 & 20.86 & 23.53 & 15.46 & 16.91 & 17.22 & 33.5 & 14.76 \\
\hline IV & & & & 0 & 10.00 & 4.56 & 11.6 & 8.48 & 19.00 & 12.00 & 4.91 & 22.32 & 12.97 & 13.44 & 21.10 & 14.73 & 18.38 & 14.73 & 16.43 & 15.73 & 27.72 & 14.43 \\
\hline $\mathbf{V}$ & & & & & 0 & 9.61 & 10.2 & 14.35 & 17.30 & 6.20 & 10.12 & 19.71 & 15.96 & 8.88 & 17.79 & 14.76 & 15.99 & 12.79 & 8.77 & 15.67 & 24.98 & 13.81 \\
\hline VI & & & & & & 0 & 13.00 & 7.56 & 19.20 & 10.00 & 6.15 & 22.75 & 12.81 & 11.03 & 21.5 & 14.34 & 20.27 & 12.77 & 16.62 & 18.6 & 27.97 & 15.97 \\
\hline VII & & & & & & & 10.80 & 15.9 & 17.70 & 14.00 & 13.17 & $\begin{array}{l}19.37 \\
\end{array}$ & 17.45 & 14.09 & 18.72 & 14.76 & 14.00 & 15.71 & 12.7 & 12.87 & 25.37 & 12.82 \\
\hline VIII & & & & & & & & 0 & 23.5 & 13.00 & 11.05 & 26.5 & 7.84 & 13.62 & 26.04 & 19.57 & 24.74 & 15.4 & 20.03 & 19.45 & 33.16 & 17.88 \\
\hline IX & & & & & & & & & 0 & 18.00 & 20.88 & 4.94 & 23.20 & 18.1 & 5.39 & 11.55 & 13.63 & 18.23 & 14.67 & 24.37 & 11.57 & 25.32 \\
\hline $\mathbf{X}$ & & & & & & & & & & 0 & 12.25 & 21.1 & 13.74 & 7.42 & 19.02 & 17.43 & 20.61 & 12.48 & 10.77 & 20.08 & 26.52 & 18.88 \\
\hline $\mathrm{X1}$ & & & & & & & & & & & 0 & 24.36 & 15.80 & 14.70 & 22.61 & 15.88 & 19.96 & 15.59 & 17.15 & 17.6 & 28.72 & 14.77 \\
\hline XII & & & & & & & & & & & & 0 & 25.33 & 20.56 & 5.37 & 14.73 & 13.65 & 20.82 & 15.08 & 25.1 & 11.35 & 26.69 \\
\hline XIII & & & & & & & & & & & & & 0 & 14.57 & 25.29 & 22.51 & 25.87 & $\begin{array}{ll}7.17 \\
\end{array}$ & 18.83 & 20.93 & 33.36 & 21.15 \\
\hline XIV & & & & & & & & & & & & & & 0 & 20.09 & 14.87 & 20.94 & 8.87 & 12.86 & 20.84 & 26.8 & 18.36 \\
\hline $\mathbf{X V}$ & & & & & & & & & & & & & & & 0 & 15.14 & 13.02 & 20.79 & 13.4 & 24.68 & 10.17 & 26.30 \\
\hline XVI & & & & & & & & & & & & & & & & 0 & 14.08 & 13.19 & 16.81 & 21.51 & 18.57 & 19.26 \\
\hline XVII & & & & & & & & & & & & & & & & & 0 & 21.40 & 14.15 & 15.17 & 17.72 & 17.5 \\
\hline XVIII & & & & & & & & & & & & & & & & & & 11.22 & 15.92 & 22.54 & 26.45 & 19.62 \\
\hline XIX & & & & & & & & & & & & & & & & & & & 0 & 17.46 & 21.48 & 18.09 \\
\hline $\mathbf{X X}$ & & & & & & & & & & & & & & & & & & & & 0 & 31.23 & 9.22 \\
\hline XXI & & & & & & & & & & & & & & & & & & & & & 9.57 & 32.25 \\
\hline XXII & & & & & & & & & & & & & & & & & & & & & & 0 \\
\hline
\end{tabular}


Among the 11 characters studied panicle weight contributed the most $(25.64 \%)$ to the genetic divergence of the genotypes followed by primaries per panicle $(22.92 \%)$ and grain yield per plant (17.85\%).

However, days to $50 \%$ flowering, days to maturity, plant height and panicle length indicated narrow range of diversity among the genotypes under study. Similar results were reported by Mahajan et al., (2010).

Promising donors identified for various economic traits can be further used for future breeding programme. Genotype IS22986 (52 days) and IS30507 (57 days) were found to be useful donors for early days to 50\% flowering, genotype IS3158 and IS29335 (115 days) for days to maturity, genotype IS12804 (92.60 g) and IS4360 (78.10) were found superior for high panicle weight, genotype IS 24503 for lengthy panicle (40.63), genotype IS29468 (52 no) for high primaries per panicle, genotype IS11026 (5.77 g) and IS31706 $(5.43 \mathrm{~g})$ for high 100 seed weight and genotypes IS12804 (66.01 g), IS4360 (64.80 g) and IS7987 $(58.06 \mathrm{~g})$ for high grain yield. Therefore these accessions should be utilized in further breeding program for developing superior varieties.

The data on inter-cluster distances were used to select genetically diverse and agronomically superior genotypes. The genotypes exceptionally good with one or more characters were seemed to be desirable.

Inter-crossing of divergent groups would lead to greater opportunity for crossing over, which releases hidden potential variability by disrupting the undesirable linkages (Thoday, 1960). The progeny derived from such diverse crosses are expected to have wide spectrum of genetic variability, providing a greater scope for isolating transgressive segregants in advanced generations. Hence, these genotypes might be used in a multiple crossing programme to recover transgressive segregants (Shivani and Sreelakshmi, 2015).

\section{References}

Aruna, C., Bhagwat, V.R., Madhusudhana, R., Vittal Sharma, Hussain, T., Ghorade, R.B., Khandalkar, H.G., Audilakshmi, S. and Seetharama, N. 2011. Identification and validation of genomic regions that affect shootfly resistance in sorghum [Sorghum bicolor (L.) Moench]. Theory Applied Genetics. 122: 1617-1630.

Doijad, S.B., Bagade, A.B. and More, A.W. 2016. Evaluation of sorghum germplasm for genetic diversity using D2 statistics. Electronic Journal of Plant Breeding. 7(4): 934-938.

Mahajan, R. C., Wadikar, P. B. and Pole, S. P. 2010. Genetic diversity studies in sorghum, (Sorghum bicolor L. Moench). Research Journal of Agricultural Sciences. 1: 332-334.

Mahalanobis, P.C. 1936. On the generalizes distance in statistics. Proceedings National Academy Sciences. 12: 49-55.

Sameer Kumar, C.V., Shreelakshmi, Ch., and Shivani D. 2010. Genetic diversity analysis in rabi sorghum [Sorghum bicolor (L.) Moench] local genotypes. Electronic Journal of Plant Breeding. 1(4): 527-529.

Santosh K., Girish, G., Dharmaraj, P. S. and Lokesha, R. 2015. Genetic diversity analysis in germplasm lines of Rabi sorghum [Sorghum bicolor (L.) Moench] based on quantitative traits. International Journal of Plant Sciences. 9(1):129-132.

Shivani D. and Sreelakshmi, Ch. 2013. Morphometric diversity of rabi sorghum germplasm lines. Forage Research. 39(1): 2023.

Shivani, D. and Sreelakshmi, Ch. 2015. Germplasm evaluation of rabi sorghum, (Sorghum bicolor (L.) M). Journal of global Biosciences. 4(8): 3150-3153.

Thoday, J.M. 1960. Effects of disruptive selectionIII coupling and repulsion. Heredity. 14: 3539.

\section{How to cite this article:}

Bhima Hari Vara Prasad and Biradar, B.D. 2017. Genetic Diversity Studies in Minicore Collection of Rabi Sorghum [Sorghum bicolor. (L)] Using D ${ }^{2}$ Statistics. Int.J.Curr.Microbiol.App.Sci. 6(7): 850-856. doi: https://doi.org/10.20546/ijcmas.2017.607.104 